TITLE:

\title{
$<$ Note> Power Takeover Occurred in M Group of the Mahale Mountains, Tanzania, in 2007
}

\author{
$\operatorname{AUTHOR}(\mathrm{S})$ : \\ Inaba, Agumi
}

CITATION:

Inaba, Agumi. <Note> Power Takeover Occurred in M Group of the

Mahale Mountains, Tanzania, in 2007. Pan Africa News 2009, 16(2): 13-15

ISSUE DATE:

2009-12

URL:

http://hdl.handle.net/2433/143510

RIGHT:

Copyright (C) Pan Africa News. 


\title{
<NOTE>
}

\section{Power Takeover Occurred in $M$ group of the Mahale Mountains, Tanzania, in 2007}

\author{
Agumi Inaba
}

Japan Monkey Centre, Japan

Male chimpanzees compete for high rank, especially, alpha status since it confers the high reproductive success $^{1,2}$. Power takeovers have been recorded, but opportunities to observe such incidents are rare. Social intelligence seems to be exhibited so much in the course of dominance competition that documentation of social interactions is theoretically important $\mathrm{t}^{3-6}$. I briefly report here some interesting episodes during the recent takeover 


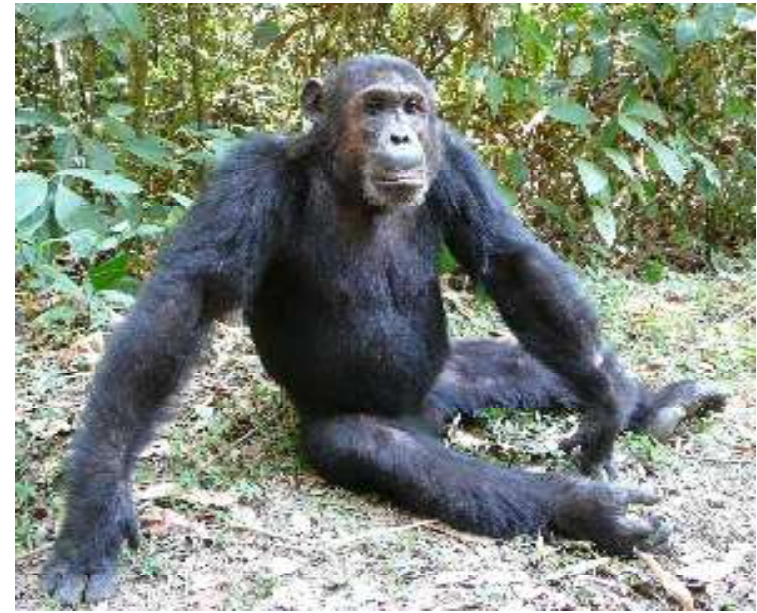

Fig. 1. Alofu, the ex-alpha male, in September 2007.

of alpha status by a young adult male.

Since 2003, in the M group of Mahale Mountains National Park, Alofu (25 years old, Fig. 1) had kept his alpha status. In 2007, however, the alpha male was changed. The beta male, Pim (19 years old, Fig. 2), challenged Alofu and then succeeded in seizing the alpha status. Back in November 2003, Fanana (alpha male, 25 years old at that time) suddenly disappeared, and Alofu (beta male, 21 years old at that time) advanced his status to alpha ${ }^{7}$. Alofu thus remained in power for three years and six months. However, according to Dr. Michio Nakamura, who stayed at Mahale in June 2007, Pim
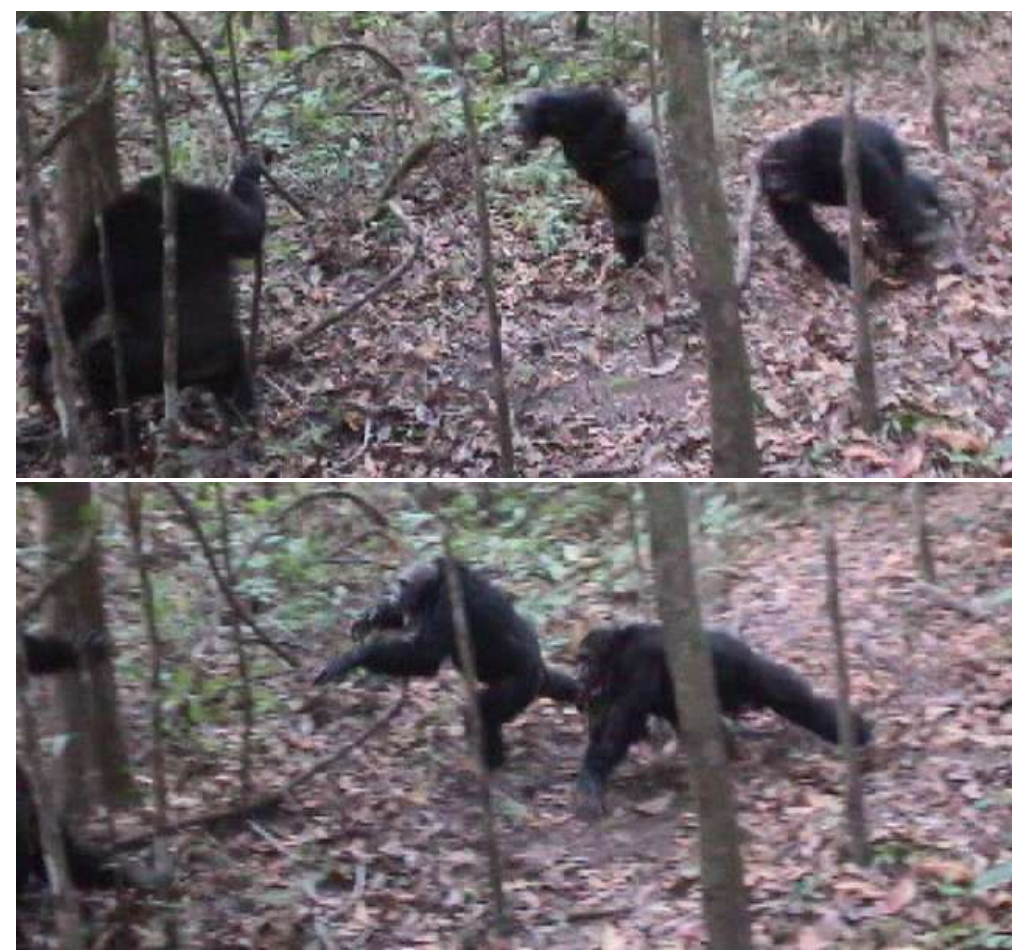

Fig. 3. Kalunde (center) began to impose himself in the agonistic relationship between Alofu and Pim. When Alofu (right) charged toward Pim (left), Pim escaped (August 2007, from video clip by Dr. Takanori Kooriyama).

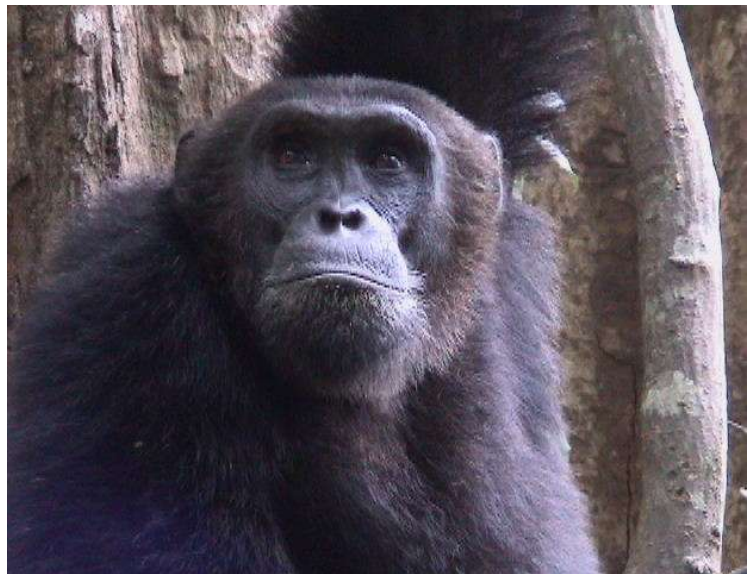

Fig. 2. Pim, the current alpha male, in September 2007.

ceased to pant-grunt to Alofu during that time. It seemed that the dominance relation between them became ambiguous. Subsequently, they seemed to fight each other, scrambling for political power up to August, but the details were unknown between June and August.

I began to study the social relationships among the adult males of $M$ group on August 10 and ended my observations on December 22, 2007. On August 17, 2007, Dr. Toshisada Nishida and I observed Alofu pant-grunting to Pim for the first time, and thus we speculated that Pim had taken over the alpha status around that time, or not long ago. Alofu's display dragged out for a long time. In contrast, Pim who was young and rough with piercing eyes, often performed short but vigorous charging displays. After the change of political power, other males of the $M$ group behaved with indecisiveness, playing up to Alofu but following Pim as well when he appeared. Alofu was not yet old, and he was still strong enough to retaliate against Pim and regain the alpha status. Nevertheless, Alofu eventually seemed to be satisfied with the beta male position. In fact, the real threat to Pim may have come from the younger rivals who had matured well. Primus (16 years old) was (and is) the principal rival, with a baby face and well-built physique, threatening Pim and Alofu. Cadmus (16 years old) is small in size but a good athlete. We would expect them to be promising candidates for the top position.

Youngsters were active, but a senior, Kalunde (about 44 years old), continued to be strong and influential in political situations. On August 28, 2007, males showed opposition to Pim over a cycling female. Although Pim solicited support from Kalunde more than once, Kalunde switched his allegiance to Alofu as soon as he saw 
Alofu rushing toward Pim, and he also gave chase to Pim (Fig. 3). Pim escaped at full speed, then returned to Kalunde hastily, and finally hugged Kalunde to make up with him. On November 13, when Pim was defeated by the team of Primus-Cadmus, other males were sitting and watching at a distance, and only Kalunde walked to Pim's side. These incidents did not have an impact on Pim's status; the power balance among highest-ranking males seemed to depend not only on the attitude of many adult males, but also on Pim's assertiveness.

There was one male who came back to the central part of the group, as if he had foreseen the change in alpha status. He was Fanana (29 years old, Fig. 4), the last alpha male but one, who had disappeared in 2003 and since then almost always ranged alone within the $\mathrm{M}$ group's territory. In August 2007, Fanana repeated some behavior patterns, such as traveling with members for a few days and then disappearing for another few days. Fanana seemed to adapt himself entirely to the group by September. On November 12, Fanana turned up, after an interval of several days, at the hill where $M$ group members were resting. Fanana came up quietly and sat in the middle of the current power coalition. Alofu, Kalunde, Cadmus and Tarnie (female, estimated 15 years old) had all been grooming in tandem. Seeing Fanana coming, all four chimpanzees turned around and sat immediately surrounding Fanana, and then they began to groom him.

Fanana engaged in vigorous social play, such as wrestling with other males, as if he were compensating for previous lost time. Furthermore, he often traveled

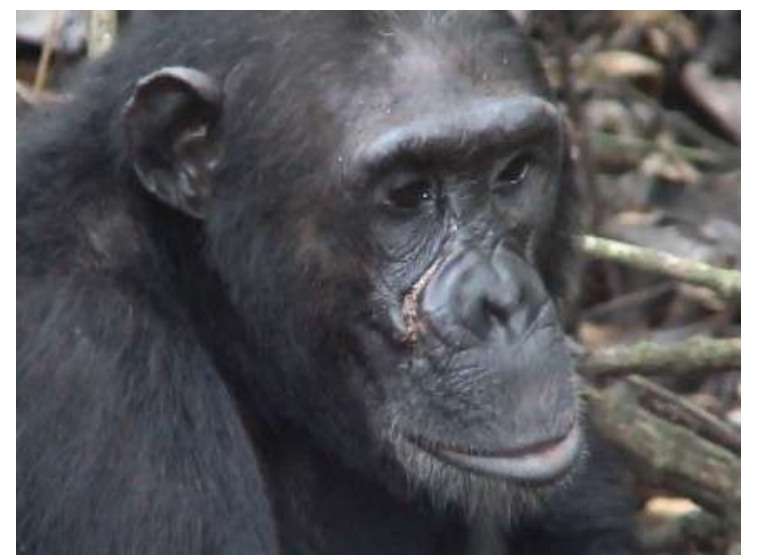

Fig. 4. Fanana coming back with fresh wound on the right side of his face (September 2007).

with Pim. Although Fanana's status fell to near the lowest end of the adult males, it seemed that Pim began to rely on Fanana to some extent. Based on these initial findings, I would like to follow the movements of the adult males of $\mathrm{M}$ group.

I thank T. Kooriyama and M. Nakamura for providing valuable information and video clips; $\mathrm{T}$. Nishida and K. Hosaka for constructive comments. The research was supported by the MEXT Grant-in-Aid for
Basic Scientific Research Fund (\#19255008 to T. Nishida) and the Global Environment Research Fund (F-061 to T. Nishida) of the Ministry of the Environment, Japan.

\section{REFERENCES}

1. Hasegawa T, Hiraiwa-Hasegawa M 1990. Sperm competition and mating behavior. In: Nishida $\mathrm{T}$ (ed) The Chimpanzees of the Mahale Mountains. University of Tokyo Press, Tokyo, pp. 115-132.

2. Inoue $\mathrm{E}$, Inoue-Murayama $\mathrm{M}$, Vigilant $\mathrm{L}$, Takenaka $\mathrm{O}$, Nishida T 2008. Relatedness in wild chimpanzees: the influence of paternity, male philopatry, and demographic factors. Am J Phys Anthropol 137:256-262.

3. de Waal FBM 1982. The Chimpanzee Politics. Jonathan Cape, London.

4. Nishida T 1983. Alpha status and agonistic alliance in wild chimpanzees (Pan troglodytes schweinfurthii). Primates 24:318-336.

5. Nishida T, Hosaka K 1996. Coalition strategies among adult male chimpanzees of the Mahale Mountains, Tanzania. In: Great Ape Societies, McGrew WC, Marchant LF, Nishida T (eds), Cambridge University Press, Cambridge, pp. 114-134.

6. Hosaka K, Nishida T 2002. Restoration of alpha status to the ostracized ex-alpha male. In: Mahale Chimpanzees: Thirty-seven Years of "Panthropology", Nishida T, Uehara S, Kawanaka K (eds) Kyoto University Press, pp. 439-471 (in Japanese).

7. Nishie H, Nishida T 2005. A new record of reclusion of an alpha male chimpanzee and his decline from the alpha status in the Mahale Mountains National Park, Tanzania. Primate Res Suppl:S-9 (in Japanese). 